\title{
Investigating the s-2 Subsite Selectivity of Alkaline Proteases in Hydrolysis of Diastereo-Peptide Esters and Molecular-Modeling Interpretation
}

\author{
Shui-Tein Chen, ${ }^{*}$ Chen-Chen Tu, ${ }^{1}$ Shiah-Yun Chen, ${ }^{1}$ Hsuan-Cheng Huang ${ }^{1}$ and \\ Kung-Tsung Wang1,2* \\ Institute of Biological Chemistry, Academia Sinica, Taiwan, R.O.C. \\ ${ }^{2}$ Department of Chemistry, National Taiwan University, PO Box 23-106, Taipei, Taiwan, 10098, R.O.C.
}

(Received 11 August 1993; accepted 22 September 1993)

\begin{abstract}
Diastereomeric peptide-esters (Ala-Ala-AA2-Phe-OMe, AA = Gly, D- or L-Ala, Pro, Phe, Lys, and Glu) have been used as substrates, and the kinetic constants $\left(K_{\text {cat }}\right.$ and $\left.K_{\mathrm{m}}\right)$ of the three alkaline proteases, subtilisin Carlsberg, alcalase, and Nagarse (subtilisin BPN') catalyzed ester-hydrolysis, were measured to investigate the selectivity of the enzyme-catalyzed peptide esterhydrolysis. All three proteases preferred the substrate which had a small side-chain at the s-2 site. Thus, the substrates with a bulky side-chain at the p-2 site such as Phe, Pro, Glu, and Lys, hydrolyzed with a rate of about one-tenth that of Ala at the p-2 site, and the $K_{\text {cat }}$ decreased as the size of the p-2 amino acid residue increased. The diastereoselectivity of the alkaline protease-catalyzed hydrolysis of each diastereomeric pair depended on the size of the amino acid residue at the p- 2 position of the substrate. The substrates with a bulky side-chain at the p-2 site hydrolyzed with higher diastereoselectivity than did the substrates with a small side-chain at the $\mathrm{p}-2$ site.

Molecular modeling of the enzyme-substrate complex show that: for the enzyme complexed with a substrate which has $L-L-L-L$ configuration, each residue of the L-L-L-L tetrapeptide filled in and was completely enclosed by the cleft of the four subsites of the enzyme. The side-chains of the residues were identically positioned within the pocket of the binding-site. For the complex of enzyme with substrate of L-L-D-L, the side-chain of the D-amino acid residue was far away from the s-2 subsite of the enzyme, and had close contact with the side-chains of Leu-126 and Ile-107 of the enzyme.
\end{abstract}

\section{Introduction}

In recent years, alkaline protease has increasingly been used for the optical resolution of chiral molecules such as amino acids, and natural products in either aqueous solution or organic solvents. ${ }^{1}$ The enzyme has also been used for peptide bond formation in anhydrous organic solvents. ${ }^{2}$ We have found that the configuration of the amino acid residue at the $\mathrm{p}-2$ site of a peptide substrate will affect the rate of ester hydrolysis in an alkaline protease "alcalase"' catalyzed ester hydrolysis, ${ }^{3}$ and will also affect the yield in an engineered alkaline protease "subtilisin 8350" catalyzed kinetically controlled peptide bond formation. ${ }^{4}$ The other bacillus alkaline protease "thermitase" also has the same diastereoselectivity. ${ }^{5}$ In order to further investigate the diastereoselectivities of the alkaline protease catalyzed hydrolysis reaction, a series of peptide esters (Ala-Ala-AA 2 -Phe-OMe, $\mathrm{AA}_{2}=\mathrm{Gly}$, D- or L-Ala, Pro, Phe, Lys, and Glu) were used as substrates. The kinetic constants $\left(K_{\text {cat }}\right.$ and $\left.K_{\mathrm{m}}\right)$ of the three alkaline proteases, subtilisin Carlsberg, alcalase, and Nagarse (subtilisin BPN') were measured to investigate the selectivity of the enzyme-catalyzed peptide ester-hydrolysis.

Alcalase is a proteolytic enzyme prepared from the submerged culture of a selective strain of Bacillus licheniformis. The major enzyme component of alcalase is the serine protease subtilisin Carlsberg (alkaline protease

Key Words-Alkaline proteases, alcalase, subtilisin Carlsberg, subtilisin BPN', diastereoselective hydrolysis, molecular modeling.
A), which is one of the most thoroughly characterized bacterial proteases. Much is understood about the kinetic properties and chemical modification behavior of this and other bacillus subtilisins. ${ }^{6}$ Nagarse (from sigma protease XXVII) has amino acid analysis and isoelectric focusing electrophoresis consistent with subtilisin BPN'.

Many crystal structures of alkaline proteases have been solved. One structure of the protease and protease inhibitor, obtained from a complex of Eglin-c and subtilisin Carlsberg, shows the mutual interaction of the hydrogen bonding between the p1-p2-p3-p4 of the Eglin-c and each subsite of subtilisin Carlsberg. ${ }^{7}$ This model was applied to interpret the results of the relative rate of enzymatic hydrolysis of each diastereomeric pair by comparing the fit of each diastereomeric substrate complexed with the test enzymes using the molecular modeling program Insight II.

\section{Results and Discussion}

\section{Synthesis of tetrapeptides}

Peptide synthesis was carried out via the preformed-active ester method. ${ }^{8}$ As shown in Scheme I, coupling of a BocAla-Ala-OH with 1-hydroxybenzotriazole ( $\mathrm{HoBt}$ ) in ethyl acetate, using dicyclohexylcarbodiimide as a coupling reagent, afforded the dipeptide active ester Boc-Ala-AlaOBt. The $N, N$-dicyclohexylurea formed as a by-product was removed by filtration. The nucleophile was prepared by dissolving the methyl ester of the dipeptide ( $\mathrm{AA}_{2}$-Phe$\mathrm{OMe} \cdot \mathrm{HCl}$ ) with one equivalent of diisopropylethylamine 
in dichloromethane. Peptide bond formation was achieved by reacting the nucleophile with the Boc-Ala-Ala-OBt, and the product was isolated simply by extraction with ethyl acetate. All the tetrapeptides were prepared this way and were purified via flash column chromatography (silica gel, eluent $\mathrm{MeOH}: \mathrm{CH}_{2} \mathrm{Cl}_{2} ; 1: 9$ ). After the peptides were purified (homogeneous by TLC and HPLC), the protecting groups, Boc and $t$-Bu, were removed by treatment with
$50 \%$ trifluoroacetic acid in dichloromethane. The deprotected tetrapeptides were evaporated three times by dissolving in methanolic hydrochloride and then recrystallization with $\mathrm{MeOH} / \mathrm{ether}$ (1:9) yielded pure substrates as characterized by melting point, optical rotation, amino acid composition analysis and NMR spectra. The results are shown in Table 1 . The yields of each coupling were about $75-85 \%$.

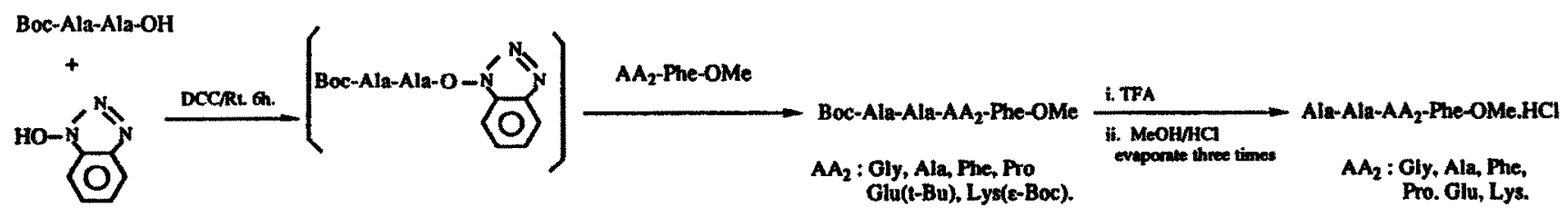

HoBt

Schome I. Synthesis of tetrapeptides using the preformed active-ester method.

Table 1. Yields and the physical data of various synthetic tetrapeptides

\begin{tabular}{|c|c|c|c|c|c|}
\hline compounds & yield & mp: $(\mathrm{C})$, & {$[\alpha]_{\mathrm{D}}^{25}: \mathrm{c} 1 \mathrm{H}_{2} \mathrm{O}$} & amino acid an & alysis \\
\hline 1 Ala-Ala-Gly-Phe-OMe.HCl & 75 & $115-117$ & -13.25 & Ala:Gly:Phe; & $2.00: 0.97: 0.99$ \\
\hline $\begin{array}{l}\text { 2.Ala-Ala-Ala-Phe-OMe.HCl } \\
\text { 3.Ala-Ala-D-Ala-Phe-OMe.HCl }\end{array}$ & $\begin{array}{l}81 \\
83\end{array}$ & $\begin{array}{l}217-218 \\
213-214\end{array}$ & $\begin{array}{l}-43.85 \\
-17.86\end{array}$ & $\begin{array}{l}\text { Ala:Phe; } \\
\text { Ala:Phe; }\end{array}$ & $\begin{array}{l}3.00: 0.99 \\
3.00: 0.99\end{array}$ \\
\hline $\begin{array}{l}4 \text { Ala-Ala-Phe-Phe-OMe.HCI } \\
5 \text { Ala-Ala-D-Phe-Phe-OMe.HCI }\end{array}$ & $\begin{array}{l}79 \\
81\end{array}$ & $\begin{array}{l}207-208 \\
197-198\end{array}$ & $\begin{array}{l}-16.67 \\
-8.60\end{array}$ & $\begin{array}{l}\text { Ala:Phe; } \\
\text { Ala:Phe; }\end{array}$ & $\begin{array}{l}2.00: 1.98 \\
2.00: 1.97\end{array}$ \\
\hline $\begin{array}{l}\text { 6 Ala-Ala-Pro-Phe-OMe.HCl } \\
\text { Z Ala-Ala-D-Pro-Phe-OMe.HCl }\end{array}$ & $\begin{array}{l}76 \\
72\end{array}$ & $\begin{array}{l}141-143 \\
135-137\end{array}$ & $\begin{array}{l}-63.15 \\
+23.57\end{array}$ & $\begin{array}{l}\text { Ala:Pro:Phe; } \\
\text { Ala:Pro:Phe; }\end{array}$ & $\begin{array}{l}2.00: 1.02: 0.99 \\
2.00: 1.01: 0.98\end{array}$ \\
\hline $\begin{array}{l}8 \text { Ala-Ala-Glu-Phe-OMe.HCl } \\
2 \text { Ala-Ala-D-Glu-Phe-OMe.HCI }\end{array}$ & $\begin{array}{l}82 \\
81\end{array}$ & $\begin{array}{l}166-168 \\
132-136\end{array}$ & $\begin{array}{l}-32.94 \\
-13.25\end{array}$ & $\begin{array}{l}\text { Ala:Glu:Phe; } \\
\text { Ala:Glu:Phe; }\end{array}$ & $\begin{array}{l}2.00: 0.99: 0.99 \\
2.00: 0.98: 0.98\end{array}$ \\
\hline $\begin{array}{l}10 \text { Ala-Ala-Lys-Phe-OMe.HCI } \\
11 \text { Ala-Ala-D-Lys-Phe-OMe.HCI }\end{array}$ & $\begin{array}{l}85 \\
81\end{array}$ & $\begin{array}{l}119-121 \\
153-157\end{array}$ & $\begin{array}{l}-22.42 \\
-10.43\end{array}$ & $\begin{array}{l}\text { Ala:Lys:Phe; } \\
\text { Ala:Lys:Phe; }\end{array}$ & $\begin{array}{l}2.00: 1.03: 0.99 \\
2.00: 1.01: 0.98\end{array}$ \\
\hline
\end{tabular}

a: 'H-nmr of L: DMSO-d $\delta$ 1.20-1.23 (d 3H), 1.29-1.32 (d 3H), 2.82-3.06 (m 2H), 3.58 (S 3H), 3.68-3.73 (m 1H), 3.79-3.89 (m 1H), 4.32-4.48 (m 2H), 7.17-7.26 (m 5H), 8.00 (S 2H), 8.07-8.15 (t 1H), 8.32-8.36 (d IH). 8.54-8.59 (d 1H): 2: D,O \& 1.16-1.19 (d 3H), 1.20-1.22 (d 3H), 1.37-1.41 (d 3H), 2.87-3.11(m 2H), 3.60 (S 3H), 3.89-3.99 (q 1H), 4.06-4.21(m 2H), 4.52-4.59(q 1H), 7.09-7.23(m 5H); 3: D 0 o 1.01-1.05 (d 3H), 1.20-1.24 (d 3H), 1.35-1.39 (d 3H), 2.80-3.20 (m 2H), 3.60 (S,3H), 3.88-3.98 (q,1H), 4.04-4.23 (m,2H), 4.53-4.58 (q,1H), 7.08-7.25 (m,5H); 4): (D 20$) 81.24-1.27$ (d.3H), 1.40-1.42 (d,3H), 2.92-3.15 (m,4H), 3.64 (S 3H), 3.91-3.95 (q 1H), 4.23-4.31 (q 1H), 4.50-4.55 (q 1H), 4.59-4.65 (q 1H), 7.23-7.35 (m 10H); 5 : D2O $80.95-0.99$ (d 3H),

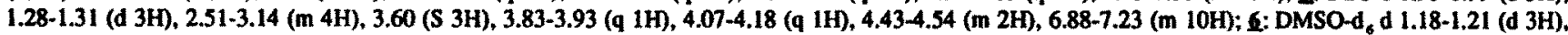
1.27-1.30 (d 3H), 1.30-2.07 (m 6H), 2.92-3.06 (m 2H), 3.77-3.93 (m 1H), 4.30-4.56 (m 3H), 7.16-7.30 (m 5H), 8.04 (S 2H), 8.15-8.19 (d 1H), 8.56-8.60 (d 1H); Z: DMSO-d 6 1.18-1.21 (d 3H), 1.27-1.30 (d 3H), 1.30-2.07 (m 6H), 2.92-3.06 (m 2H), 3.77-3.93 (m 1H), 4.30-4.56 (m 3H), 7.16-7.30 (m 5H), 8.04 (S 2H). 8.15-8.19 (d 1H). 8.56-8.60 (d IH); 8 DMSQ-d $81.16-1.19$ (d 3H), 1.29-1.32 (d 3H), 1.67-1.92 (m 2H), 2.16-2.21 (t 2H), 2.88-3.05 (d 2H), 3.57 (S 3H), 3.81-3.83 (m 1H), 4.26-4.46 (m 3H), 7.18-7.28 (m 5H), 7.96-7.99 (d 1H), 8.01 (S 2H), 8.34-8.37 (d 1H), 8.48-8.51 (d 1H); 2: DMSO-d $81.20-1.22$ (d 3H), 1.29-1.31 (d 3H), 1.48-1.77 (m 2H), 1.90-2.00 (m 2H), 2.83-3.08 (m 2H), 3.60(S 3H), 3.80-3.88 (m 1H), 4.31-4.49 (m 3H), 7.16-7.26 (m 5H), 8.03-8.06 (d 1H), 8.45-4.48 (d 1H). 8.51-8.53 (d 1H); 10 D D $_{2}$ 1.19-1.31 (m 5H), 1.39-1.42 (d 3H), 1.49-1.57 (m 4H), 2.81-2.87 (m 2H), 2.91-3.17 (m 2H), 3.60 (S 3H), 3.94-4.27 (m 3H), 4.55-4.63 (m IH), 7.11-7.24 (m 5H): 11: D, O 8 1.19-1.31 (m 5H), 1.39-1.42 (d H), 1.49-1.57 (m 4H), 2.81-2.87 (m 2H), 2.91-3.17 (m $2 \mathrm{H}), 3.60(\mathrm{~S} \mathrm{3H}), 3.94-4.27(\mathrm{~m} \mathrm{3H}), 4.55-4.63(\mathrm{~m} 1 \mathrm{H}), 7.11-7.24(\mathrm{~m} 5 \mathrm{H})$. 


\section{Kinetics of tetrapeptides in aqueous solution}

Kinetics of alcalase-catalyzed hydrolysis of each diastereomeric pair of tetrapeptide esters were conducted in phosphate buffer (pH 8.1,2 mL) containing various amounts of substrate (1.5-50 mg) and enzymes (0.001-15 $\mathrm{mg}$ ). The conversion of the substrate to the product was monitored by HPLC. In most cases, $0.1-0.5 \mathrm{U}$ of alcalase was used for the reaction of $\mathrm{L}$-diastereomer, and 1.0-15 U of enzyme was used for the D-epimer to hydrolyze enough peptides for analysis. No peptide bond cleavage was observed during ester hydrolysis as checked by HPLC with authentic samples. Figure 1 shows typical kinetic data corresponding to Lineweaver Burke plots for the reactions of Ala-Ala-Ala-Phe-OMe (L-L-L-L and L-L-D-L), the correlation coefficient being $>90 \%$ in each case.

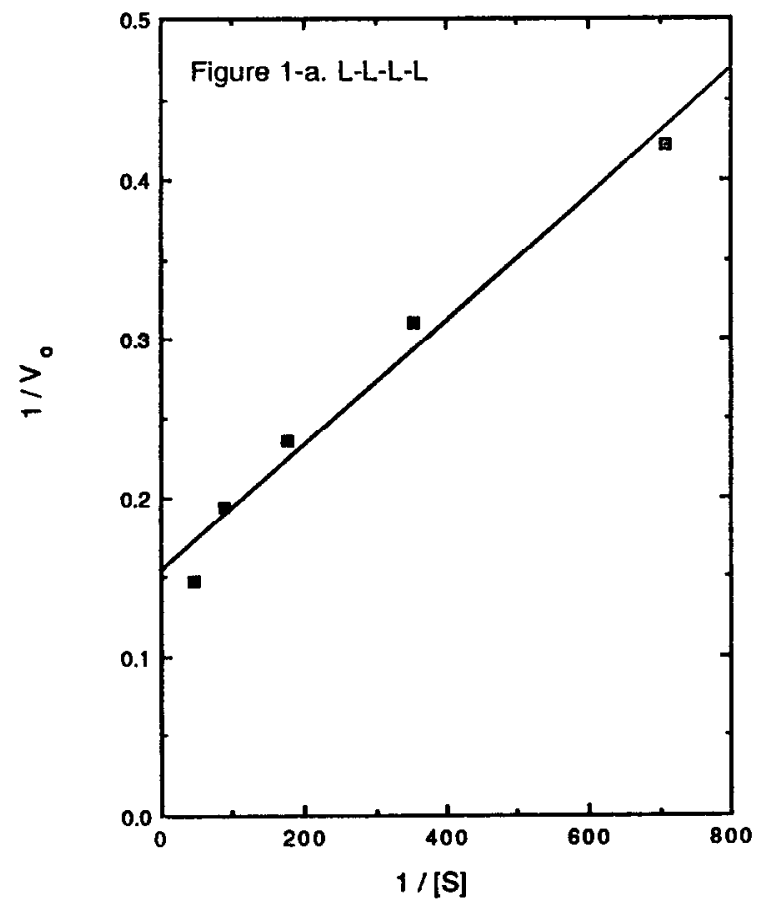

Table 2 shows the kinetics $\left(K_{\text {cat }}\right.$ and $K_{\mathrm{m}}$ ) of alcalase, subtilisin Carlsberg and Nagarse catalyzed hydrolysis of the tetrapeptide esters. All three proteases preferred the substrate which had a small side-chain at the $s-2$ site. Thus the substrates with bulky side-chains at the p-2 site such as Phe, Pro, Glu, and Lys, hydrolyzed with a rate of about one-tenth that of Ala at the p-2 site, and the $K_{\text {cat }}$ decreased as the size of the p-2 amino acid residue increased. Using alcalase as a catalyst, the Ala-Ala-Gly-Phe-OMe hydrolyzed faster than did the Ala-Ala-Ala-Phe-OMe. The substrate with Glu at the p-2 site hydrolyzed at the same rate as did the substrate with Phe at the p-2 site, and the substrate with Lys at the p-2 site hydrolyzed at twice the rate of the substrate with $P$ he at the $\mathrm{p}-2$ site.

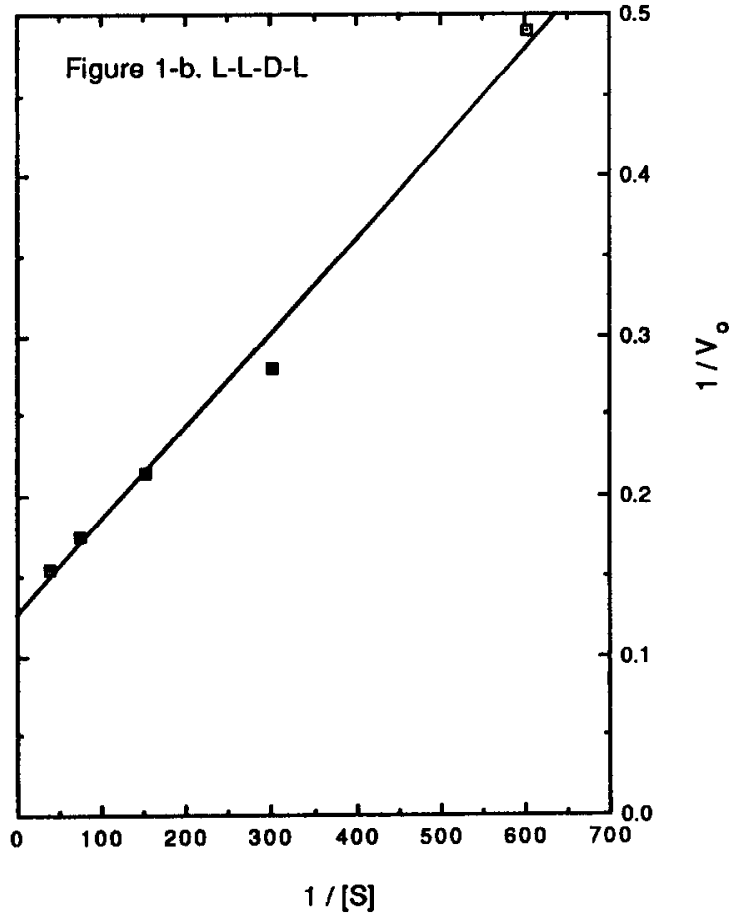

Figure 1. Lineweaver Burke plots for the alcalase-catalyzed hydrolysis of Ala-Ala-Ala-Phe-OMe. (a) Shows the plots of $1 / V_{0}$ vs $1 /[\mathrm{S}]$ for the hydrolysis of L-L-L-L peptide. (b) Shows the plots of $1 / V_{0} v s 1 /[S]$ for the hydrolysis of L-L-D-L peptide

Table 2. Kinetic constants of alkaline proteases catalyzed hydrolysis of various tetrapeptides

\begin{tabular}{|c|c|c|c|c|c|c|c|c|c|}
\hline \multirow[b]{2}{*}{ Substrateslenzyme used } & \multicolumn{3}{|c|}{ Kcat $\left[\min ^{-1}\right]$} & \multicolumn{3}{|c|}{$\mathrm{Km} \times 10^{3}[\mathrm{M}]$} & \multicolumn{3}{|c|}{ Kcav $\mathrm{Km} \times 10^{3}\left[\mathrm{~min}^{-1} \mathrm{M}^{-1}\right]$} \\
\hline & AL, & SC, & $\overline{N A}$ & AL, & SC, & $\overline{N A}$, & $\mathrm{AL}$, & SC, & $\overline{\text { NA }}$ \\
\hline Ala-Ala-Gly-Phe-OMe. & 1490 & & & 2.12 & & & 702.83 & & \\
\hline $\begin{array}{l}\text { Ala-Ala-Ala-Phe-OMe. } \\
\text { Ala-Ala-D-Ala-Phe-OMe. }\end{array}$ & $\begin{array}{l}1401 \\
17.18\end{array}$ & $\begin{array}{l}3589 \\
81.1\end{array}$ & $\begin{array}{l}2202 \\
61.7\end{array}$ & $\begin{array}{l}2.68 \\
4.48\end{array}$ & $\begin{array}{l}1.541 \\
2.587\end{array}$ & $\begin{array}{l}12.2 \\
7.83\end{array}$ & $\begin{array}{l}522.76 \\
3.83\end{array}$ & $\begin{array}{l}2329 \\
31.3\end{array}$ & $\begin{array}{l}180.5 \\
7.88\end{array}$ \\
\hline $\begin{array}{l}\text { Ala-Ala-Phe-Phe-OMe. } \\
\text { Ala-Ala-D-Phe-Phe-OMe. }\end{array}$ & $\begin{array}{l}97.04 \\
0.143\end{array}$ & $\begin{array}{l}389.7 \\
1.418\end{array}$ & $\begin{array}{l}305.8 \\
5.48\end{array}$ & $\begin{array}{l}4.24 \\
1.93\end{array}$ & $\begin{array}{l}5.43 \\
3.43\end{array}$ & $\begin{array}{l}8.83 \\
5.79\end{array}$ & $\begin{array}{l}22.87 \\
0.074\end{array}$ & $\begin{array}{l}71.76 \\
0.413\end{array}$ & $\begin{array}{l}34.63 \\
0.946\end{array}$ \\
\hline $\begin{array}{l}\text { Ala-Ala-Pro-Phe-OMe. } \\
\text { Ala-Ala-D-Pro-Phe-OMe. }\end{array}$ & $\begin{array}{l}103.2 \\
0.825\end{array}$ & $\begin{array}{l}405.5 \\
13.63\end{array}$ & $\begin{array}{l}580.3 \\
4.04\end{array}$ & $\begin{array}{l}8.17 \\
23.7\end{array}$ & $\begin{array}{l}5.85 \\
34.3\end{array}$ & $\begin{array}{l}14.1 \\
5.21\end{array}$ & $\begin{array}{l}12.63 \\
0.035\end{array}$ & $\begin{array}{l}69.32 \\
0.397\end{array}$ & $\begin{array}{l}41.16 \\
0.775\end{array}$ \\
\hline $\begin{array}{l}\text { Ala-Ala-Glu-Phe-OMe. } \\
\text { Ala-Ala-D-Glu-Phe-OMe. }\end{array}$ & $\begin{array}{l}106.0 \\
0.541\end{array}$ & $\begin{array}{l}416.4 \\
0.471\end{array}$ & $\begin{array}{l}145.5 \\
0.478\end{array}$ & $\begin{array}{l}4.07 \\
14.8\end{array}$ & $\begin{array}{l}10.62 \\
6.683\end{array}$ & $\begin{array}{l}2.31 \\
3.31\end{array}$ & $\begin{array}{l}26.04 \\
0.036\end{array}$ & $\begin{array}{l}39.20 \\
0.070\end{array}$ & $\begin{array}{l}62.99 \\
0.144\end{array}$ \\
\hline $\begin{array}{l}\text { Ala-Ala-Lys-Phe-OMe. } \\
\text { Ala-Ala-D-Lys-Phe-OMe }\end{array}$ & $\begin{array}{l}262.3 \\
0\end{array}$ & & & $\begin{array}{l}108 \\
-\end{array}$ & & & 2.43 & & \\
\hline
\end{tabular}

a. AL, alcalase; SC, subtilisin Carlsberg. NA, subtilisin BPN' (Nagarse). 
The diastereoselectivity of the alkaline protease-catalyzed hydrolysis of each diastereomeric pair depended on the size of the amino acid residue at the $\mathrm{p}-2$ position of the substrate. In the course of ester hydrolysis, each pair of substrates with a bulky side-chain at the p-2 site hydrolyzed with higher diastereoselectivity than did the substrate with a small side-chain at the p- 2 site. The ratio of turnover rate $\left(K_{\text {cat }} / K_{\mathrm{m}}\right.$ of L-L-L-L divided by $K_{\text {cat }} / K_{\mathrm{m}}$ of L-L-D-L) of alcalase catalyzed hydrolysis of Ala-Ala-PhePhe-OMe was 746.1:1 and that of Ala-Ala-Ala-Phe-OMe was 74.1:1. Figure 2 shows the ratio of turnover rate of each diastereomeric pair catalyzed by the three enzymes. All the enzymes had the same trend in the hydrolysis of the substrate.

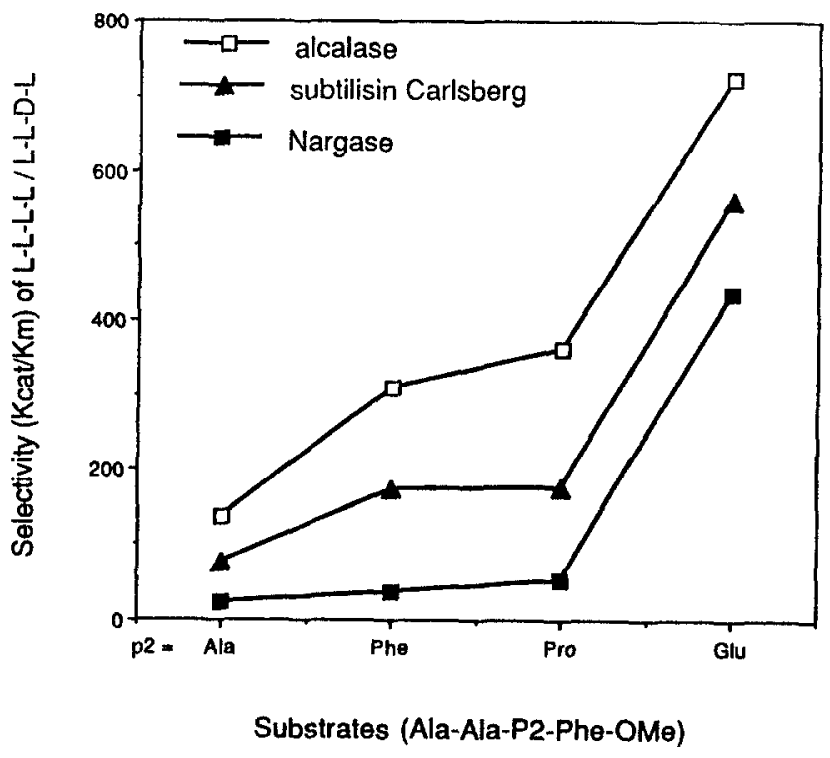

Figure 2. Diastereoselectivity of alcalase, subtilisin Carlsberg, and Nagarse catalyzed hydrolysis of four pairs of peptide-diastereomers

\section{Modeling of tetrapeptide in the active site of subtilisin Carlsberg}

Several crystal structures of the alkalinc protcase and of the enzymes complexed with inhibitors have been determined in high resolution. ${ }^{8}$ The subtilisin Carlsberg structure has been highly refined to $1.4 \AA$ resolution $(R$-factor $=0.14)$ and has revealed structural details for three ion binding sites. This forms a good basic modeling of various enzyme-substrate intermediates. The structures of the diastereomeric tetrapeptides (L-L-L-L and L-L-D-L) were positioned into the crystal structure of the active site of subtilisin Carlsberg using the computer program Insight II. Figure 3 depicts the possible structure of the enzymesubstrate (L-L-L-L form) complex. The subtilisin Carlsberg-substratc complex shares several prominent features originally found in the subtilisin Carlsbergreactive-site loop of the Eglin-c complex. Each residue of the L-L-L-L tetrapeptide fills and is completely enclosed by the cleft of the four subsites. The side-chains of the residues are identically positioned within the pocket of the binding-site. The backbones of the substrate are held in place by the strong hydrogen bonds via the carbonyl $(C=O)$ and amide $(\mathrm{N}-\mathrm{H})$ of the substrate and the enzyme's backbone. Scheme II shows the mutual interaction of the hydrogen bonding between the p1-p2-p3-p4 of the Eglin-c and each subsite of the subtilisin Carlsberg. The p-2 binding site is surrounded by the amino acid residues Gly100 , His-64, Thr-33, and Leu-96, in which the imidazole ring of His-64, $\mathrm{C}^{2}$ of Thr-33 and the side chain of Leu-96 form a narrow hydrophobic pocket.

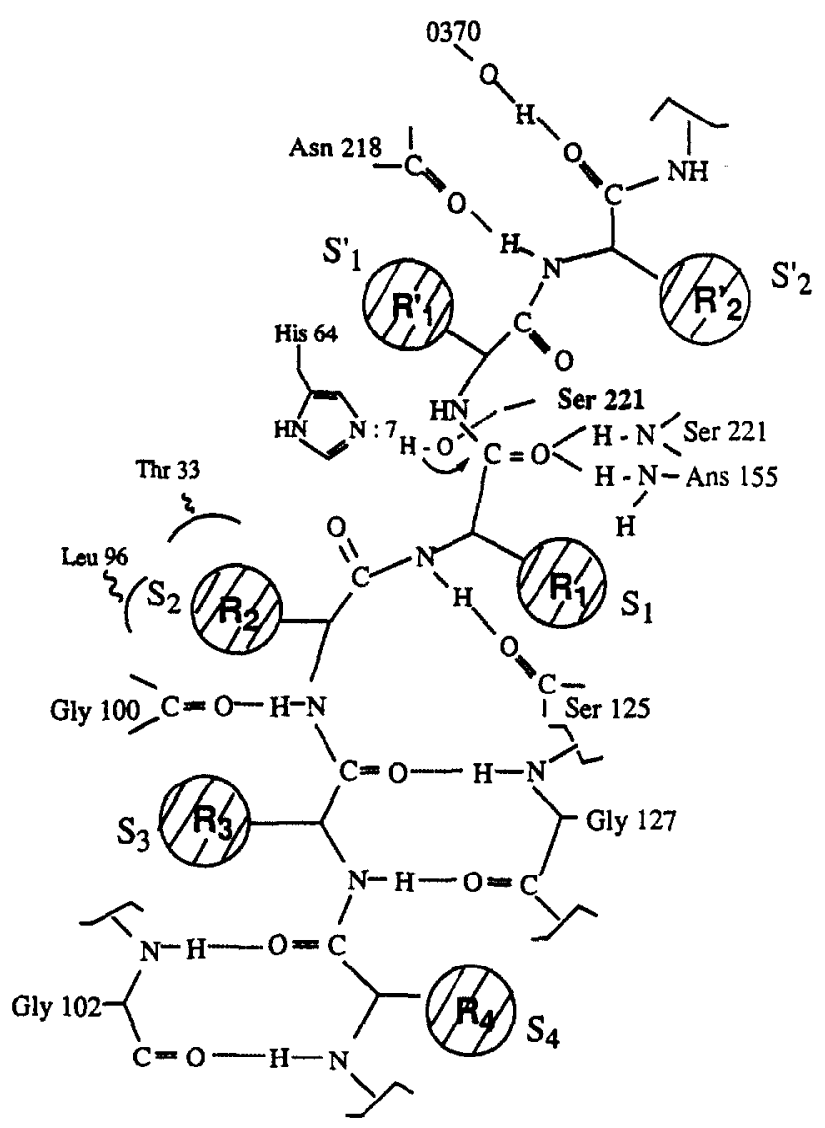

Scheme II. Possible structure of substrate-enzyme complex deduced from X-ray crystal.

The L-L-L-L substrate was positioned along with the four subsites of the enzyme in an anti-parallel complex. Comparing the structure of the L-L-L-L with that of the LL-D-L, the backbone of the L-L-D-L tetrapeptide is L-shaped with the p-2 amino acid oriented vertically. In modeling of the L-L-D-L peptides, there are two possible ways to fit the substrate into the cleft of the active site. Because the p-2 amino acid residue of the substrate is the D-form, the backbone orientation of the substrate differs by $90^{\circ}$ from the L-form antipode. In the first fitting, we considered that the substrates could be hydrolyzed by the enzyme. Thus the $\mathrm{p}-1$ residue was placed into the active sites and the $\mathrm{p}-2, \mathrm{p}-3$ and $p-4$ residues were extended to the axis which differs by $90^{\circ}$ from the orientation of L-L-L-L. Scheme III(a) depicts the possible orientation of the stereo-arrangement of the complex. In this fit, the side-chain of the D-amino acid residue was far away from the s-2 sub-site of the enzyme, and had close contact with the side-chains of Leu-126 and Ile-107 of the enzyme. 


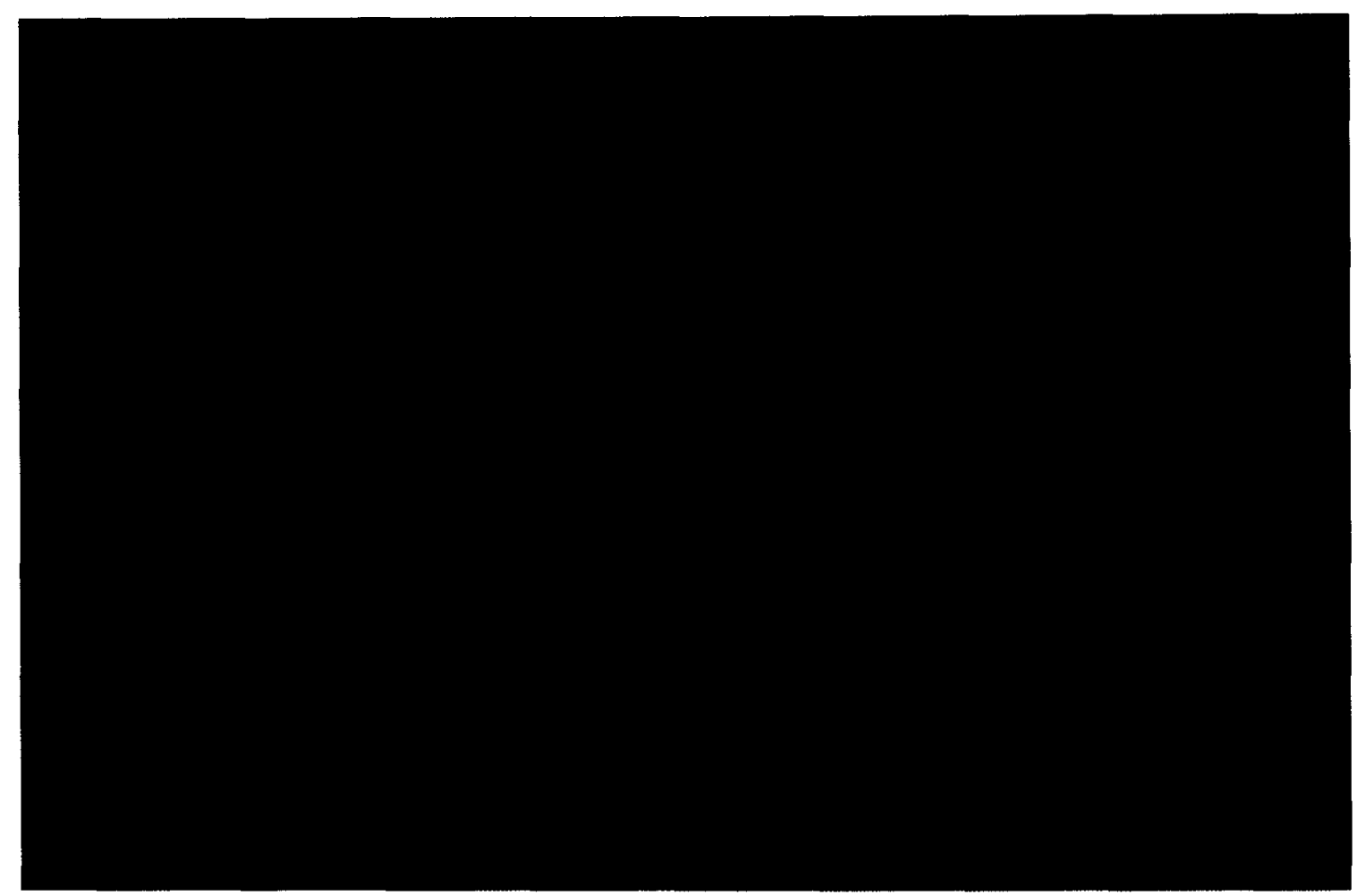

글

ब

울을

g

蛋

일

$8 \%$

믄

융용

․ㅠ곡

昰

은

究

융

블 봉

政

卷导

要号

究产

芉势

영 트을 


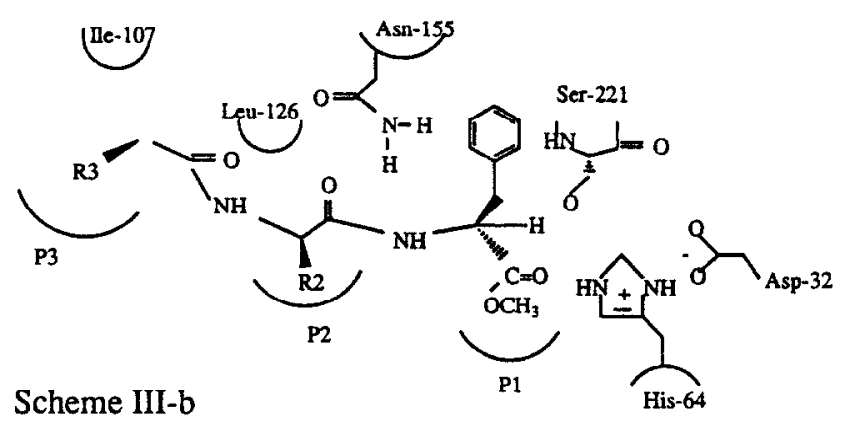

Scheme III-a

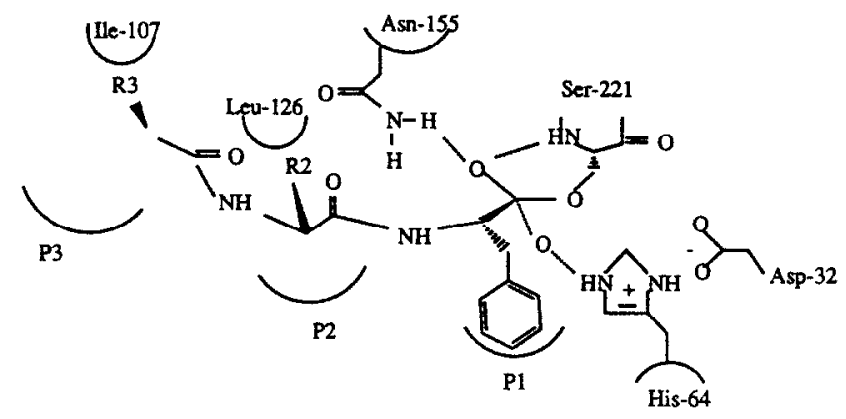

Scheme III. Possible structure of the L-L-D-L tetrapeptide in the active site of subtilisin Carlsberg.

In the second fitting, the $\mathrm{p}-4, \mathrm{p}-3$ and $\mathrm{p}-2$ residues of the substrate were placed into the cleft of each corresponding active site with suitable hydrogen-binding, and the p-1 residue could not be placed into the $\mathrm{p}-1$ site. This left the scissile bond of the methyl ester far away from the nucleophile of Ser-219 of the enzyme, and the substrate could not be hydrolyzed. Scheme III(b) depicts the possible structure of this fit.

In conclusion, the $s-2$ subsite of the alkaline protease is small. The substrate with a small amino acid residue at the p-2 site hydrolyzed faster than did the substrate with a bulky amino acid residue at the $\mathrm{p}-2$ site. The diastereoselectivity also depended on the size of the p-2 amino acid residue. The amino acid has a large sidechain, which is hydrolyzed with high selectivity. Using the $s-2$ site selectivity of alkaline proteases-catalyzed hydrolysis to synthesize small and racemization-free peptides has been proved to be a convenient way. The kinetic constants and the selectivities reported here provide a good reference to predict what kind of peptides can be prepared with high optical purity.

\section{Experimental}

Alcalase was purchased from NOVO industrial as a brown liquid with a specific activity of $2.5 \mathrm{Au} / \mathrm{mL}$. It was used without further purification. The amino acids, subtilisin Carlsberg, and Nagarse were purchased from Sigma, U.S.A. Dicyclohexylcarbodiimide and hydroxybenzotriazole were purchased from E. Merck, Germany.
The substrates were prepared by using the established method and purified to homogeneity on TLC and HPLC. The amino acid methyl esters were prepared in methanol with ten equivalents of thionyl chloride. Optical rotation was measured on a Universal Polarimeter (Schmidt \& Haensch, Germany). The HPLC system consisted of two Waters Model 6000 pumps, a Waters Model 450 UV detector, and an M-660 solvent programmer. TLC was performed on silica gel $\mathrm{G}$ pre-coated plates (E. Merck, Germany). Methanol, ethyl acetate, methylene chloride, acetonitrile, dioxane, ether, and acetone (HPLC grade and reagent grade) were obtained from a local supplier (ALPS Chem. Co., Taiwan). The coordinates for the alcalase (subtilisin A) or subtilisin Carlsberg were obtained from the Protein Data Bank at Brookhaven National Laboratory. 9,10

\section{Synthesis of Substrates}

\section{Ala-Ala-Ala-Phe-OMe-HCl L-L-L-L as an example}

Dicyclohexylcarbodiimide $(2.06 \mathrm{~g}, 10 \mathrm{mmol})$ was added to a solution of Boc-Ala-Ala-OH $(2.67 \mathrm{~g}, 10 \mathrm{mmol})$ and HoBt $(1.80 \mathrm{~g}, 12 \mathrm{mmol})$ in ethyl acetate $(30 \mathrm{~mL})$ and DMF $(5 \mathrm{~mL})$. The mixture was stirred for $5-6 \mathrm{~h}$ at room temperature and filtered to remove the dicyclohexylurea. To the filtrate was added a solution of Ala-Phe-OMe-HCl $(3.48 \mathrm{~g}, 12 \mathrm{mmol})$ in dichloromethane $(20 \mathrm{~mL})$ and diisopropylethylamine $(2.04 \mathrm{~mL}, 12 \mathrm{mmol})$, and the resulting mixture was stirred for 3-4 h. The mixture was diluted with ethyl acetate $(150 \mathrm{~mL})$, and washed with 0.1 M HCl (4 x $20 \mathrm{~mL})$, water $(30 \mathrm{~mL}), 5 \%$ sodium bicarbonate $(4 \times 20 \mathrm{~mL})$, water $(4 \times 20 \mathrm{~mL})$ and then dried over anhydrous sodium sulfate. Evaporating the organic solvent gave the crude product, which was purified with flash column chromatography (silica gel, eluent $\left.\mathrm{MeOH}: \mathrm{CH}_{2} \mathrm{Cl}_{2} ; 1: 9\right)$ yield $4.07 \mathrm{~g}(81 \%)$ m.p.: $157-159$ ${ }^{\circ} \mathrm{C},[\alpha]_{\mathrm{D}}{ }^{25}:-10.91^{\circ}$ (c $\left.2.0 \mathrm{MeOH}\right)$. The Boc-Ala-Ala-AlaPhe-OMe (2.01 g, $4 \mathrm{mmol}$ ) was dissolved in a mixture of trifluoroacetic acid $(10 \mathrm{~mL})$ and dichloromethane $(10 \mathrm{~mL})$, and the resulting mixture was stirred at room temperature for $30 \mathrm{~min}$. The solvent was evaporated under reduced pressure. The residue was dissolved and evaporated three times with $5 \%$ methanolic hydrochloride. The hydrochloride salt of the deprotected tetrapeptide crystallized during the evaporation. The material was recrystallized from methanol/ether $(1: 5,30 \mathrm{~mL})$ to yield pure Ala-AlaAla-Phe-OMe-HCl (1.69 g, 93\% yield). The physical data of m.p., optical rotation, amino acid analysis and NMR spectra are shown in Table 1.

\section{Enzyme Assays}

Alcalase $(100 \mu \mathrm{L})$, subtilisin Carlsberg $(30 \mu \mathrm{g})$, or Nagarse was dissolved in phosphate buffer $(\mathrm{pH}=6.0,5.0$ $\mathrm{mL}$ ) at room temperature. Periodically, $100 \mu \mathrm{L}$ aliquots were removed and added to a cuvette containing $0.20 \mu \mathrm{mol}$ of Z-Lys-SBzl, $0.40 \mu \mathrm{mol}$ of 4,4'-dithiodipyridine, and 900 $\mu \mathrm{L}$ of $0.2 \mathrm{M}$ phosphate buffer containing $10 \% \mathrm{v} / \mathrm{v}$ of $\mathrm{DMF}(\mathrm{pH}=8.2)$. The initial reaction rates were determined from time-dependent plots of the increasing absorbance at $324 \mathrm{~nm}$. 


\section{Kinetics of Enzyme Catalyzed Ester Hydrolysis}

The kinetic values of the alkaline protease-catalyzed reaction were determined by varying the substrate concentration and measuring the initial rates using HPLC. These initial rates were fitted to the Michaelis-Menten equation by using a nonlinear least-squares computer program. The concentration of substrates ranged from 0.005 to $0.050 \mathrm{M}$, and the amount of the enzyme was increased 2-, 4-, 8-, and 10-fold. HPLC was used to measure the concentrations of reacted and unreacted peptide esters using an RP-8 column with $0.1 \%$ trifluoroacetic acid in $45 \%$ acetonitrile as eluent. The conversion of the substrate to the product was calculated by using an initial concentration as $100 \%$.

\section{Computer Graphics of Enzyme-Substrate Complex}

The interactive molecular graphics computer program used to model the fit of the enzyme-substrate complex was Insight II, running on a personal iris $4 \mathrm{D} / 35$ of silicon graphics. The models of the substrates were built using standard bond lengths and bond angles. The energy minimization was performed by allowing the dihedral angles at non-carboxylic single bonds in the substrate and at side-chain bonds of the enzymes to be flexible. The phenyl ring of the substrate was placed in the hydrophobic pocket (s-1 site) of the enzyme formed residues Leu-126, Gly-127, Ala-152, Gly-154 and Asn-155. The methyl ester to be hydrolyzed by the enzyme was positioned for nucleophilic attack by $\gamma$-oxygen of Ser-221 with the carboxylic oxygen oriented toward potentially hydrogen bonding peptide amide groups of Ser-221 and Asn-155. In the model of the complex the substrate was allowed to move relative to the enzymes.

\section{Acknowledgements}

Support for this research provided by the National Science Council of the R.O.C. is gratefully acknowledged.

\section{References}

1. Schutt, H.; Schmidt-Kastner, G.; Arens, A.; Preiss, M. Biotech. Bioeng. 1985, 27, 420-423; Ricks, E. E.; EstradaValdes, M. C.; McLean, T. L.; Iacobucci, G. A. Biotech. Prog. 1992, 8, 197-203; Roper, J. M.; Bauer, D. P. Synthesis 1983, 1041; Chen, S. T.; Wang, K. T.; Wong, C. H. Chem. Commun. 1986, 1514-1516; Chen, S. T.; Chen, S. Y.; Hsiao, S. C.; Wang, K. T. Biotech. Lett. 1991, 13(11), 773778; Chen, S. T.; Hsiao, S. C.; Wang, K. T. BioMed. Chem. Lett. 1991, 1(9), 445-450; Zhong, Z.; Liu, J. J. C.; Dinterman, L. M.; Finkelman, M. A. J.; Mueller, T. W.; Rollence, M. L.; Whitlow, M.; Wong, C. H. J. Am. Chem. Soc. 1991, 113, 683-684.

2. Kise, H.; Bioorg. Chem. 1990, 18, 107-115; Chen, S. T.; Hsiao, S. C.; Wang, K. T. BioMed. Chem. Lett. 1991, 1(9), 445; Chen, S. T.; Chen, S. Y.; Wang, K. T. J. Org. Chem. 1992, 57, 6960-6965.

3. Chen, S. T.; Wu, S. H.; Wang, K. T. Int. J. Peptide Protein Res. 1991, 37, 347-350.

4. Wong, C. H.; Chen, S. T.; Hennen, W. J.; Bibbs, J. A.; Wang, Y. F.; Liu, J. L. C.; Pantoliano, M. W.; Whitlow, M.; Bryan, P. N. J. Am. Chem. Soc. 1990, 112, 945-953.

5. Schon, I. Thesis, Fak. Naturwiss. Univ. Hall, 1985.

6. Philipp, M.; Bender, M. L. Molec. Cell. Biochem. 1983. 51, 5-32; and references cited therein.

7. McPhalen, C. A.; James, M. N. G. Biochem. 1988, 27, 6582-6598; Bode, W.; Paramokos, E.; Musil, D. Eur. J. Biochem. 1987, 166, 673-692.

8. Bodanszky, M.; Bodanszky, A. In The Practice of Peptide Synthesis, Springer-Verlag; Berlin, 1984.

9. Bernstein, F. C.; Koetzle, T. F.; Williams, G. J. B.; Meyer, Jr, E. F.; Brice, M. D.; Rodgers, J. R.; Kennard, O.; Shimanouchi, T.; Tasumi, M. J. Molec. Biol. 1977, 112, 535-542.

10. Abola, E. E.; Bernstein, F. C.; Bryant, S. H.; Koetzle, T. F.; Weng, J. Protein Data Bank, in Crystallographic Databases-information Content, Software System, Scientific Applications, pp. 107-132, Allen, F. H.; Bergerhoff, G.; Sievers, R., Eds.; Data Commission of the International Union of Crystallography, Bonn, 1987. 